\title{
Sheep grazing spotted knapweed and Idaho fescue
}

\author{
BRET E. OLSON AND ROSEANN T. WALLANDER
}

Authors are associate professor and research associate, Department of Animal and Range Sciences, Montana State University, Bozeman, Mont. 597172900.

\section{Resumen}

\begin{abstract}
Spotted knapweed (Centaurea maculosa Lam.), an Eurasian perennial forb, is replacing many native perennial grasses, such as Idaho fescue (Festuca idahoensis Elmer.), throughout the Northern Rocky Mountain region. Our objective was to determine sheep use of spotted knapweed and Idaho fescue during 3 consecutive summers (1991-1993). Each summer, 3 small spotted knapweed infested pastures were grazed for 5-8 days in midJune, 2-6 days in mid-July, and 1-6 days in early September. Nutritive value of spotted knapweed leaves and flowerheads were consistently higher than of Idaho fescue. Nutritive value for both species declined as the summer progressed. The sheep readily grazed spotted knapweed, but they also grazed other plants, including the native Idaho fescue. They did not consistently graze 1 species more than another, which may have reflected daily weather patterns, slight differences in forage nutritive value, or cyclic grazing patterns which are often associated with plants containing secondary compounds, such as spotted knapweed. At the end of many grazing periods, heights of grazed spotted knapweed plants were greater than those of Idaho fescue, which reflected how the sheep grazed leaves and avoided fibrous stems of mature spotted knapweed plants, whereas they were not selective when grazing Idaho fescue. Although the sheep did not graze spotted knapweed exclusively, probably because animals seek diverse diets, their use of this noxious weed may help restore a balance in competitive relations between this noxious weed and native grasses.
\end{abstract}

Key Words: weed, Centaurea maculosa, Festuca idahoensis, utilization, nutritive value

Spotted knapweed (Centaurea maculosa Lam.), an aggressive, introduced perennial forb, is replacing native perennial grasses throughout the Northern Rocky Mountain region (Tyser and Key 1988, Lacey et al. 1995). Herbicides, fire, and biocontrol insects and pathogens are not containing the spread of this noxious weed. Large herbivores rarely graze spotted knapweed, possibly because it contains cnicin, a bitter tasting compound (Watson and Renny 1974, Kelsey and Locken 1987, Locken and Kelsey 1989). Where large herbivores such as cattle and horses avoid spotted knapweed, this noxious weed can outcompete native grasses for water and nutrients.

In contrast to large herbivores, the anatomy and morphology of small ruminants are more conducive for foraging on broad-leaved

We thank Kathrin Olson-Rutz for reviewing the manuscript. This study was supported by the Montana Department of Agriculture (Noxious Weed Trust Fund MDA 91-13a) and the Montana Agricultural Experiment Station.

Manuscript accepted 19 Mar. 2000.
El "Spotted knapweed"(Cenaturea maculosa Lam.) es una hierba perenne originaria de Eurasia que en la región norte de las montañas Rocallosas esta remplazando muchos de los zacates nativos, como el "Idaho fescue" (Festuca idahoensis Elmer.),. Nuestro objetivo fue determinar durante tes veranos consecutivos (1991-1993) el consumo de "Spotted knapweed" y "Idaho fescue" por borregos. Cada verano 3 potreros pequeños infestados de "Spotted knapweed" se apacentaron durante 5-8 días a mediados de Junio, 2-6 días a mediados de Julio y 1-6 días a principios de Septiembre. El valor nutritivo de las hojas e inflorescencias del "Spotted knapweed" fue consistentemente más alto que el del "Idaho fescue" El valor nutritivo de ambas especies disminuyo a medida que el verano avanzó. Los borregos apacentaron con gusto el "Spotted knapweed", pero también apacentaron otras plantas, incluyendo el pasto nativo "Idaho fescue". Los borregos no apacentaron en forma consistente una especie mas que otra, lo cual pudo haber reflejado patrones climáticos diarios, ligeras diferencias en el valor nutritivo del forraje o patrones cíclicos de apacentamiento que a menudo son asociados con plantas que contienen compuestos secundarios, tal como el "Spotted knapweed". Al final de muchos periodos de apacentamiento la altura de las plantas apacentadas de "Spotted knapweed"fue mayor que la de "Idaho fescue", lo cual refleja que los borregos consumieron hojas evitando los tallos fibrosos de las plantas maduras de "Spotted knapweed" mientras que no fueron selectivos cuando apacentaron el "Idaho fescue". Aunque los borregos no apacentaron exclusivamente "Spotted knapweed", porque ellos probablemente buscan dietas diversificadas, el consumo de esta planta nociva por los borregos puede restablecer el balance en las relaciones competitivas entre esta especie nociva y los zacates nativos.

plants containing secondary defense compounds, such as spotted knapweed (Hofmann 1989). In general, sheep prefer broad-leaved herbs to grasses and shrubs (Hanley 1982), possibly because broad-leaved herbs tend to be more nutritious and digestible than grasses (Shipley 1999). Conversely, the native bunchgrass Idaho fescue (Festuca idahoensis Elmer.) "increases" with sheep grazing (USDA 1983), presumably because sheep prefer broad-leaved herbs and certain grasses to Idaho fescue.

In a greenhouse study, a single defoliation did not affect spotted knapweed, whereas defoliations at monthly intervals reduced root and crown weights, and carbohydrate concentrations in roots, crowns, and stems (Kennett et al. 1992, Lacey et al. 1994). This sequence of multiple defoliations was duplicated in a field study, where we assessed impacts of sheep grazing a spotted knapweed-infested community for 3 consecutive summers (Olson and Wallander 1997, Olson et al. 1997). This community was 
grazed repeatedly by sheep, in mid-June when spotted knapweed was bolting, in mid-July when the native bunchgrass Idaho fescue (Festuca idahoensis Elmer.) was dormant, and in early September before the Idaho fescue resumed fall growth.

Our objective was to assess use of spotted knapweed and Idaho fescue by sheep during these 3 periods during the summers of 1991-1993. If sheep graze spotted knapweed more than the associated native grasses, this may help restore a balance to the plant community (Olson 1999).

\section{Methods and Materials}

The study site was $14 \mathrm{~km}$ south of Bozeman, Mont. (45 $\left.36^{\prime} \mathrm{N} 111^{\circ} 4^{\prime} \mathrm{W}\right)$ at an elevation of $1,570 \mathrm{~m}$. Soil was a shallow to moderately deep, silty clay loam over sand and gravel Typic Argiboroll class, Beaverton series on an alluvial fan (USDA 1995). The 30-year precipitation average for the nearest weather station (Bozeman, Mont.) was $487 \mathrm{~mm}$. Precipitation for 1991-1993 was 99, 115, and $123 \%$ of the 30 -year average, respectively. The summer (June-August) of 1991 was drier and warmer than the 30year average, whereas the summers of 1992 and especially 1993 were cooler and wetter than the long term average (Table 1). In mid-June 1991, standing crop aver-

Table 1. Thirty-year averages and 1991-1993 mean temperatures and total precipitation for May through August, Bozeman, Mont.

\begin{tabular}{|c|c|c|c|c|c|c|c|c|}
\hline \multirow[b]{2}{*}{ Month } & \multicolumn{4}{|c|}{ Temperature } & \multicolumn{4}{|c|}{ Precipitation } \\
\hline & $\begin{array}{l}\text { 30-year } \\
\text { average }\end{array}$ & 1991 & 1992 & 1993 & $\begin{array}{l}30 \text {-year } \\
\text { average }\end{array}$ & 1991 & 1992 & 1993 \\
\hline & & 100 & C) - - & $-1 .-$ & 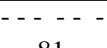 & - - - & -- & --- \\
\hline May & 10.8 & 10.0 & 13.5 & 13.5 & 81 & 134 & 70 & 84 \\
\hline Jun. & 15.6 & 15.0 & 16.8 & 14.2 & 73 & 48 & 140 & 108 \\
\hline Jul. & 19.6 & 20.6 & 16.9 & 14.7 & 34 & 13 & 43 & 125 \\
\hline Aug. & 18.8 & 21.4 & 17.9 & 16.0 & 38 & 12 & 23 & 73 \\
\hline
\end{tabular}

aged $1,580 \mathrm{~kg} \mathrm{ha}^{-1}$; the plant community was dominated by Idaho fescue $(41 \%)$ and spotted knapweed (25\%). In mid-June 1992, standing crop averaged 2,201 $\mathrm{kg} \mathrm{ha}^{-1}$; again, the plant community was dominated by Idaho fescue $(50 \%)$ and spotted knapweed (16\%). Standing crop was not measured in 1993. Other common species at the site were bluebunch wheatgrass (Pseudoroegnena spicata (Pursh) Love), Kentucky bluegrass (Poa pratensis L.), arrowleaf balsamroot (Balsamorhiza sagittata (Pursh) Nutt.), lupine (Lupinus senceus Pursh), and sticky geranium
(Geranium viscosissimum F. \& M.).

Three 0.1-ha pastures enclosed with Electronet $^{\mathrm{R}}$ fencing were randomly located within a 3-ha area. The area had previously been grazed by horses for 10 years, which had encouraged the spread of spotted knapweed. Other than our sheep, domestic herbivores did not graze in or adjacent to our small pastures during the study.

Four, 10-m permanent transects were established inside each small pasture. Permanent plots $\left(0.5-\mathrm{m}^{2}\right)$ were established at 1-m intervals along each transect. The cue to each corner of the $0.5-\mathrm{m}^{2}$ plots were marked with colored wire before grazing each year. Heights of these marked plants were recorded immediately before the sheep grazed each period (day 0).

Each pasture was grazed by 5 Targhee yearling ewes during the summers of 1991-1993. New animals which had never been exposed to spotted knapweed were used each year. Each pasture was grazed for 5 to 8 days in mid-June, 2 to 6 days in mid-July, and 1 to 6 days in early September. Duration of the grazing periods depended on available forage. When not in the study pastures, the sheep were grazed nearby in areas with $10-20 \%$ spotted knapweed cover.

When the sheep were in the study pastures, use of marked spotted knapweed and Idaho fescue plants was recorded nearest spotted knapweed and Idaho fes-

plants of similar diameter. Finally, grazed and ungrazed heights were recorded.

To determine nutritive value, ungrazed and regrowth from previously grazed spotted knapweed and Idaho fescue plants were harvested while the sheep were grazing each study pasture. All ungrazed spotted knapweed plants were air-dried, and separated into leaves, stems, and flower buds. Regrowth from previously grazed spotted knapweed plants was sorted into leaves and stems. Idaho fescue plants were separated into leaves (culmless stems) and flowering stems (culmed stems). All plant parts were ground to pass through a $1-\mathrm{mm}$ screen in a Wiley mill. Crude protein $(\% \mathrm{~N}$ $\mathrm{x} 6.25$; CP) was determined by a standard method (AOAC 1984). Neutral detergent fiber (NDF) and acid detergent fiber (ADF) were determined by the procedures of Goering and Van Soest (1970). In vitro dry matter disappearance (IVDMD) was determined after Tilley and Terry (1963).

Within each grazing period (June, July, September) each year (1991-1993), grazed plant frequency, percent canopy removed, and grazed plant heights were analyzed with a repeated measures analysis of variance (day 0 , day 2 , etc.) as a randomized-complete-block design ( $\mathrm{n}=3$; GLM, SAS 1988). Plant species was the between treatment effect; day within grazing period was the within treatment effect. Analyses of grazed plant frequency and percent canopy removed were based on observations after day 0 . Analyses of grazed plant heights included day 0 . Because some of the distributions were not spherical, we used Huynh-Feldt adjusted P-values. Because of inherent variability in field studies such as this one, P-values less than 0.15 are presented (Gill 1981).

every 48 hours (day 2, day 4, etc.). First, impact to the marked plant was recorded as none, grazed, trampled, or grazed and trampled. "Grazed" and grazed and trampled" categories were combined to determine grazed plant frequency. This included any evidence of grazing in the preceding 2 day interval. Lack of any necrotic tissue at grazed leaf tips indicated recent grazing compared with necrotic tissue at leaf tips which indicated grazing during the previous grazing period. Second, percent canopy removed of grazed plants was estimated by comparing with ungrazed

\section{Nutritive value}

Crude protein in leaves from ungrazed and previously grazed spotted knapweed plants was consistently greater than those from Idaho fescue (Tables 2,3). Crude protein in stems from ungrazed and previously grazed spotted knapweed plants was similar to levels in flowering stems of Idaho fescue. Neutral- and acid detergent fiber of leaves from ungrazed and previously grazed spotted knapweed plants was consistently lower than those from Idaho fescue. Neutral- and acid detergent fiber of stems from ungrazed and previously grazed spotted knapweed plants was similar to or slightly lower than the fiber con- 
Table 2. Nutritive value (crude protein, neutral detergent fiber, acid detergent fiber, in vitro dry matter disappearance) of leaves (L), stems (S), and flower heads (F) collected from ungrazed (U) and regrowth from previously grazed (G) spotted knapweed plants during the June (JUN), July (JUL), and September (SEP) grazing periods 1991-1993. Values represent means from samples collected from each pasture (n = 3). "na" indicates not available.

\begin{tabular}{|c|c|c|c|c|c|c|c|c|c|c|}
\hline & & \multicolumn{3}{|c|}{1991} & \multicolumn{3}{|c|}{1992} & \multicolumn{3}{|c|}{1993} \\
\hline & & JUN & JUL & SEP & JUN & JUL & SEP & JUN & JUL & SEP \\
\hline \multicolumn{11}{|c|}{ crude protein } \\
\hline \multirow[t]{3}{*}{$\mathrm{U}$} & $\mathrm{L}$ & 12 & 6 & na & 13 & 10 & 5 & 13 & 12 & 9 \\
\hline & $\mathrm{S}$ & na & 3 & 3 & 5 & 3 & 2 & 4 & 3 & 3 \\
\hline & $\mathrm{F}$ & na & na & 8 & 20 & 11 & 8 & na & 13 & 9 \\
\hline \multirow[t]{2}{*}{ G } & $\mathrm{L}$ & na & 18 & 18 & na & 19 & 18 & na & 21 & 13 \\
\hline & $\mathrm{S}$ & na & 5 & 3 & na & na & 2 & na & na & 3 \\
\hline \multicolumn{11}{|c|}{ neutral detergent fiber } \\
\hline \multirow[t]{3}{*}{$\mathrm{U}$} & $\mathrm{L}$ & 24 & 29 & na & 20 & 21 & 27 & 22 & 22 & 28 \\
\hline & $\mathrm{S}$ & na & 65 & 77 & 55 & 61 & 71 & 58 & 57 & 58 \\
\hline & $\mathrm{F}$ & na & na & 42 & 26 & 45 & 56 & na & 27 & 50 \\
\hline \multirow[t]{2}{*}{ G } & $\mathrm{L}$ & na & 26 & 29 & na & 24 & 21 & na & na & 22 \\
\hline & $\mathrm{S}$ & na & 65 & 73 & na & na & 78 & na & na & 61 \\
\hline \multicolumn{11}{|c|}{ acid detergent fiber } \\
\hline \multirow[t]{3}{*}{$\mathrm{U}$} & $\mathrm{L}$ & 23 & 28 & na & 20 & 21 & 27 & 20 & 20 & 26 \\
\hline & $\mathrm{S}$ & na & 50 & 60 & 45 & 47 & 57 & 46 & 44 & 47 \\
\hline & $\mathrm{F}$ & na & na & 33 & 21 & 34 & 42 & na & 27 & 36 \\
\hline \multirow[t]{2}{*}{ G } & $\mathrm{L}$ & na & 21 & 25 & na & 19 & 18 & na & na & 21 \\
\hline & $\mathrm{S}$ & na & 53 & 58 & na & na & 64 & na & na & 47 \\
\hline \multicolumn{11}{|c|}{ in vitro dry matter disappearance } \\
\hline \multirow[t]{3}{*}{$\mathrm{U}$} & $\mathrm{L}$ & 68 & 61 & na & 60 & 68 & 45 & 66 & 60 & 52 \\
\hline & $\mathrm{S}$ & 57 & 37 & 19 & 56 & 43 & 29 & 52 & 46 & 38 \\
\hline & $\mathrm{F}$ & na & na & 43 & 51 & 54 & 43 & na & 55 & 46 \\
\hline \multirow[t]{2}{*}{$\mathrm{G}$} & $\mathrm{L}$ & na & 48 & 52 & na & 68 & 56 & na & 60 & 77 \\
\hline & $\mathrm{S}$ & na & 38 & 24 & na & na & 21 & na & na & 11 \\
\hline
\end{tabular}

tent of flowering stems of Idaho fescue. In vitro dry matter disappearance of leaves from ungrazed and previously grazed spotted knapweed plants was consistently greater than those from Idaho fescue. Similarly, in vitro dry matter disappearance of stems from ungrazed and previ- ously grazed spotted knapweed plants was greater than those from flowering stems of Idaho fescue.

\section{1}

During the 6 day June grazing period (15 June to 21 June), grazed plant frequen- cies of spotted knapweed and Idaho fescue increased similarly (day, $\mathrm{P}=0.002$, Fig. 1). Percent canopy removed from spotted knapweed and Idaho fescue also increased similarly (day, $\mathrm{P}=0.02$ ). Within this period, we did not measure grazed plant heights until the last day.

Table 3. Nutritive value (crude protein, neutral detergent fiber, acid detergent fiber, in vitro dry matter disappearance) of leaves (L) and flower stems (FS) collected from ungrazed (U) and regrowth from previously grazed (G) Idaho fescue plants during the June (JUN), July (JUL), and September (SEP) grazing periods 1991-1993. Values represent means from samples collected from each pasture $(n=3)$. "na" indicates not available.







Fig. 1. Grazed plant frequency (\%), canopy removed $(\%)$, and grazed plant heights $(\mathrm{cm})$ of spotted knapweed (C - Centaurea maculosa) and Idaho fescue (F - Festuca idahoensis) within grazing periods in mid-June, midJuly, and early September of 1991. Grazing periods varied based on available forage. Error bars represent \pm 1 S.E. The "*" indicates we did not measure heights of grazed plants these first 3 intervals.

During the 2 day July grazing period (16 July to 18 July), grazed plant frequency of spotted knapweed was greater than of Idaho fescue (species, $\mathrm{P}=0.01$ ). Percent canopy removed from spotted knapweed was greater than that removed from Idaho fescue (species, $\mathrm{P}=0.03$ ). Heights of grazed spotted knapweed plants did not change whereas heights of grazed Idaho fescue plants decreased (day by species, $\mathrm{P}$ $=0.008$ ).

For the 1 day September grazing period (1 September to 2 September), grazed plant frequency of spotted knapweed was lower than of Idaho fescue (species, $\mathrm{P}=$ $0.07)$. Percent canopy removed from spotted knapweed was lower than that
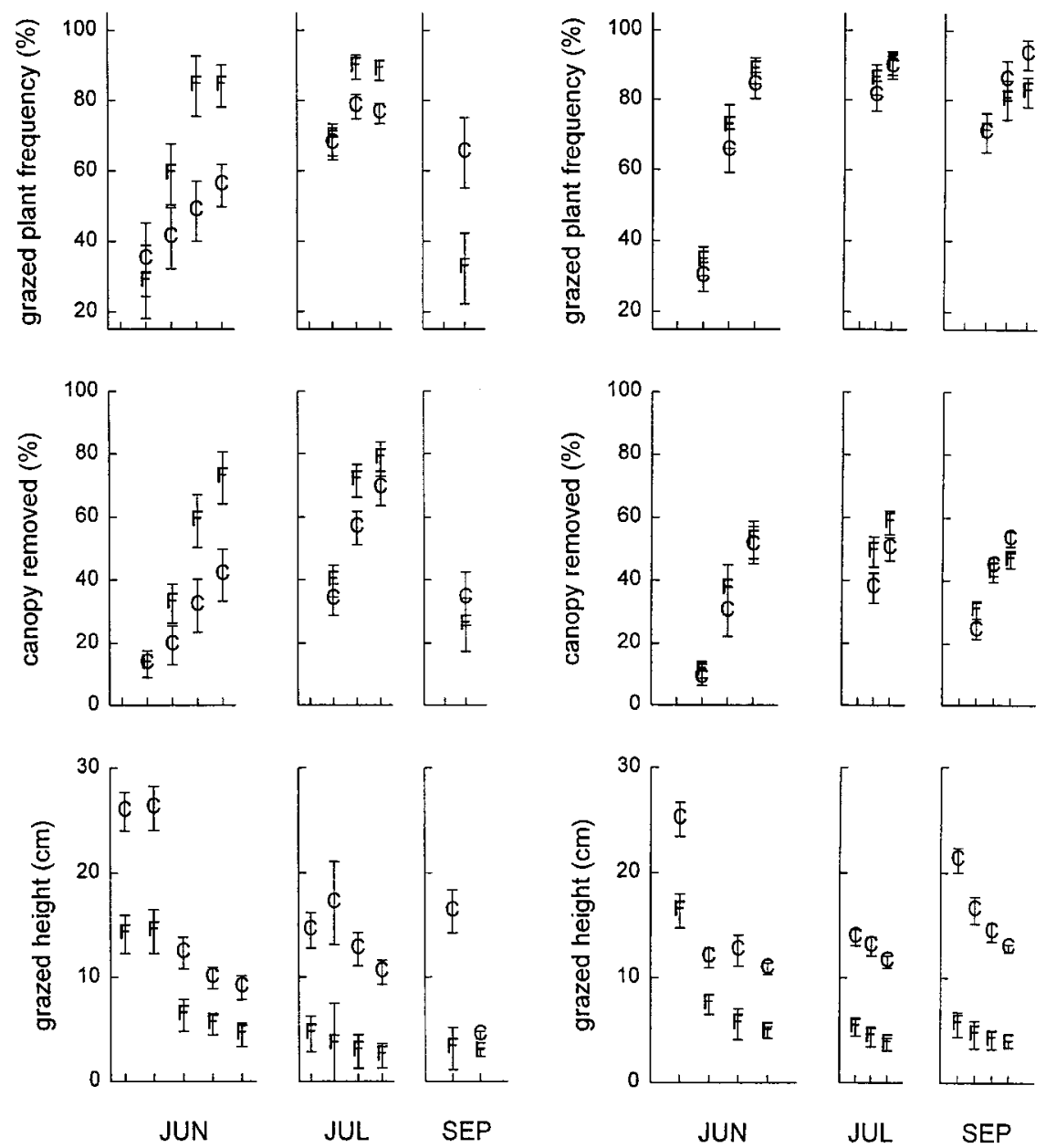

Fig. 2. Grazed plant frequency (\%), canopy removed $(\%)$, and grazed plant heights $(\mathrm{cm})$ of spotted knapweed (C - Centaurea maculosa) and Idaho fescue (F - Festuca idahoensis) within grazing periods in mid-June, midJuly, and early September of 1992. Grazing periods varied based on available forage. Error bars represent \pm I S.E.

removed from Idaho fescue (species, $\mathrm{P}=$ 0.03 ). Grazed plant heights of both species declined (day, $\mathrm{P}=0.03$ ).

\section{2}

During the 8 day June grazing period (18 June to 26 June), grazed plant frequency of Idaho fescue increased at a faster rate than grazed plant frequency of spotted knapweed (day by species, $\mathrm{P}=0.001$, Fig. 2 ). Percent canopy removed from both species was similar on day 2 , but increased at a greater rate for Idaho fescue through day 8 (day by species, $\mathrm{P}=$ 0.0004 ). Heights of grazed Idaho fescue plants declined more than heights of
Fig. 3. Grazed plant frequency (\%), canopy removed $(\%)$, and grazed plant heights $(\mathrm{cm})$ of spotted knapweed (C - Centaurea maculosa) and Idaho fescue (F - Festuca idahoensis) within grazing periods in mid-June, midJuly, and early September of 1993. Grazing periods varied based on available forage. Error bars represent \pm I S.E. grazed spotted knapweed plants (day by species, $\mathrm{P}=0.03$ ).

During the 6 day July grazing period (19 July to 25 July), grazed plant frequencies of these 2 species were similar on day 0 , but were greater for Idaho fescue than spotted knapweed on day 4 and day 6 (day by species, $P=0.12$ ). Percent canopy removed from spotted knapweed and Idaho fescue increased similarly (day, P < 0.0001). Heights of grazed Idaho fescue and spotted knapweed plants declined similarly (day, $\mathrm{P}=0.15$ ).

By the end of the 2 day September grazing period (10 September to 12 September), grazed plant frequency of spotted knapweed was greater than of 
Idaho fescue (species, $\mathrm{P}=0.08$ ). Percent canopy removed from both species was similar (species, $\mathrm{P}=0.53$ ). Heights of grazed spotted knapweed plants declined more than $50 \%$, whereas the decline was less for the short-statured Idaho fescue (day by species, $\mathrm{P}=0.01$ ).

\section{3}

During the 5 day June grazing period (20 June to 25 June), grazed plant frequency of spotted knapweed and Idaho fescue increased similarly (day, $\mathrm{P}=0.0001$, Fig. $3)$. The increase in percent canopy removed from spotted knapweed and Idaho fescue was similar (day, $\mathrm{P}=0.0001$ ). Heights of grazed Idaho fescue plants declined more, on a percentage basis, than heights of grazed spotted knapweed plants (day by species, $\mathrm{P}=0.12$ ).

During the 4 day July grazing period (14 July to 18 July), grazed plant frequency of spotted knapweed and Idaho fescue increased similarly (day, $\mathrm{P}=0.008$ ), and percent canopy removed increased similarly (day, $\mathrm{P}=0.002$ ). Heights of grazed spotted knapweed and Idaho fescue plants declined similarly (day, $\mathrm{P}=0.0008$ ).

During the 6 day September grazing period (3 September to 9 September), grazed plant frequency of spotted knapweed and Idaho fescue was similar on day 2 , but was greater for spotted knapweed than Idaho fescue on day 4 and 6 (day by species, $P=0.02$ ). Percent canopy removed from spotted knapweed was initially lower than that removed from Idaho fescue (day 2), but similar on day 4 and 6 (day by species, $\mathrm{P}=0.04$ ). Heights of grazed spotted knapweed plants declined more than of grazed Idaho fescue plants (day by species, $\mathrm{P}=0.003$ ).

\section{Discussion}

By the traditional measures of forage nutritive value (CP, NDF, ADF, IVDMD), spotted knapweed is more nutritious than Idaho fescue, so sheep should graze it readily. Yet despite spotted knapweed's high nutritive value, it was not consistently grazed more than Idaho fescue. Cnicin, a sesquiterpene lactone, in spotted knapweed may have limited grazing of this weed. Sheep rumen microbial populations are negatively affected when a sheep's diet contains $70 \%$ or more spotted knapweed, especially when the diet consists of mature leaves or flower heads which have high cnicin concentrations (Olson and Kelsey 1997). High cnicin concentrations in leaves and flowerheads of spotted knap- weed may offset the potential benefits associated with its high crude protein and low fiber content.

Sheep grazed the spotted knapweed, but they also grazed the native bunchgrasses, including Idaho fescue. Herbivores desire mixed diets containing a variety of nutrients (Provenza 1996). Even when presented with ad lib amounts of a food that meet their nutritional needs, lambs select a varied diet (Provenza et al. 1996). Animals may select varied diets for 1 or more of the following reasons: 1) animals are inherently curious and often sample foods, 2) a diverse diet often represents a balanced diet, or 3) a diverse diet may counter toxic effects associated with secondary compounds, such as cnicin in spotted knapweed.

Grazing patterns among periods differed slightly each of the 3 summers. By using a new set of "inexperienced" ewes each summer, there was no opportunity to acquire a long term preference for or aversion to spotted knapweed. In the first summer (1991), numerous standing stems of the previous year's spotted knapweed were present, but they did not deter use of the new growth at the base of the plant. With their relatively small muzzles, sheep grazed new growth surrounded by the previous year's stems. In the summers of 1992 and 1993, there were few ungrazed stems remaining from the previous year.

Use patterns within grazing periods often varied among the 2 day observation intervals. This could simply reflect responses to weather or cyclic patterns of grazing (Pfister et al. 1997). Weather patterns differed considerably between years; the summer (June-August) of 1991 was drier and warmer than the 30-year average, whereas the summers of 1992 and especially 1993 were cooler and wetter than the long term average. These could have influenced forage nutritive value, and therefore grazing patterns within each summer and among summers. Cyclic grazing, varying the intake of toxic plant compounds from day-to-day, may limit the potential cumulative effects of certain secondary compound (Pfister et al. 1997).

We used 3 different measures of utilization: grazed plant frequency, percent canopy removed, and grazed plant heights. Grazed plant frequency and plant heights are quantitative, whereas percent canopy removed is a visual estimate of how much was removed during a grazing period relative to an estimate of the intact canopy at the beginning of each grazing period. Grazed plant frequencies are usually greater than percent canopy removed, because only a small bite from a plant constitutes "grazed" for grazed plant frequency. Our grazing system mimicked an intensive grazing system which counters an animal's ability to select preferred forages. Grazed plant frequencies were often in the 80 and 90 percent range, indicating that the sheep were sampling most plants.

The estimate "percent canopy removed" often tracked "grazed plant frequency", although the values were considerably less. Both variables are measured rapidly, yet percent canopy removed is more meaningful ecologically, representing material remaining for subsequent foraging or for protecting soil from erosion. It is an estimate, though, and may vary from observer to observer, or even within an observer during the day as fatigue sets in. We recorded heights of ungrazed and grazed plants. Instead of averaging ungrazed and grazed heights, we report only grazed plant heights. Averaging the 2 would provide an overall estimate of use, but this estimate is greatly influenced by grazed plant frequency, one of our variables. Further, the average could be influenced by a few tall plants. In contrast, grazed plant heights indicate to what extent individual plants were grazed, which influences their ability to compete for water and nutrients (Briske and Richards 1995).

Grazed plant heights were usually taller on spotted knapweed than Idaho fescue plants, especially at the end of the July and September grazing periods. This does not necessarily indicate greater use of Idaho fescue for 2 reasons. First, most of the aboveground biomass of Idaho fescue, like most bunchgrasses, is close to the soil surface; the relatively few, flexible flowering stems are readily grazed. In contrast, flowering stems of spotted knapweed bolt in mid- to late June. After bolting, a greater percentage of spotted knapweed's biomass is in the upper part of the plant compared with Idaho fescue. In addition, spotted knapweed stems are thicker and more fibrous (Kelsey and Mihalovich 1987) than Idaho fescue stems. Our sheep would often remove the developing flowerheads and stem leaves of spotted knapweed, but would not graze much of the stem, resulting in "taller" heights of grazed spotted knapweed plants. Second, based on leaf heights, ungrazed spotted knapweed plants are inherently taller than ungrazed Idaho fescue plants in mid-summer $(60 \mathrm{~cm}$ versus $29 \mathrm{~cm}$, respectively). Thus, these taller, more rigid stems of spotted knapweed explain the greater grazed plant heights of this noxious weed. 
Based on grazed plant frequency, sheep often grazed Idaho fescue more than spotted knapweed which may partly reflect the plants we marked to determine use. In this study, most of our marked plants were moderate in size (mean stem basal area: spotted knapweed $4 \mathrm{~cm}^{2}$ ) Idaho fescue 22 $\mathrm{cm}^{2}$ ). In our companion study, we found that sheep grazing altered the age-class distribution of spotted knapweed plants (Olson et al. 1997). Apparently, the sheep selected younger $(<3$ years-old $)$, smaller, presumably more palatable spotted knapweed plants. We had marked few plants in these age classes to estimate use. By grazing younger, more nutritious spotted knapweed along with mature plants, a longterm commitment to sheep grazing has the potential to restore a balance to infested plant communities (Olson 1999).

\section{Conclusion}

Sheep readily grazed spotted knapweed, but they also grazed other plants, including the native Idaho fescue. It is unlikely that we will identify an herbivore which would only graze a certain species, such as spotted knapweed, because animals seek diverse diets. Nonetheless, sheep grazing spotted knapweed-infested communities may help restore a balance in competitive relations between this noxious weed and native grasses, compared with communities grazed by large herbivores which avoid spotted knapweed.

\section{Literature Cited}

AOAC. 1984. Official methods of analysis (14th ed.). Association of Official Analytical Chemists. Washington, D.C.

Briske, D.D. and J.H. Richards. 1995. Plant responses to defoliation: a physiologic, morphologic and demographic evaluation, $\mathrm{p}$. 635-710. In: D.J. Bedunah and R.E. Sosebee (eds.), Wildland plants: physiological ecology and developmental morphology. Soc. Range Manage., Denver, Colo.

Gill, J.L. 1981. Evolution of statistical design and analysis of experiments. J. Dairy Sci. 64:1494-1519.

Goering, H.K. and P.J. Van Soest. 1970. Forage fiber analysis (apparatus, reagents, procedures, and some applications). ARS, USDA Agr. Handb. 379.

Hanley, T.A. 1982. The nutritional basis for food selection by ungulates. J. Range Manage. 35:146-151.

Hofmann, R.R. 1989. Evolutionary steps of ecophysiological adaptation and diversification of ruminants: A comparative view of their digestive system. Oecologia 78:443-457.
Kelsey, R.G. and U. Locken. 1987. Phytotoxic properties of cnicin, a sesquiterpene lactone from Centaurea maculosa (spotted knapweed). J. Chem. Ecol. 13:19-33.

Kelsey, R.G. and R.D. Mihalovich. 1987. Nutrient composition of spotted knapweed (Centaurea maculosa). J. Range Manage. 40:277-281.

Kennett, G.A., J.R. Lacey, C.A. Butt, K.M. Olson-Rutz, and M.R. Haferkamp. 1992. Effects of defoliation, shading and competition on spotted knapweed and bluebunch wheatgrass. J. Range Manage. 45:363-369.

Lacey, J.R., K.M. Olson-Rutz, M.R. Haferkamp, and G.A. Kennett. 1994. Effects of defoliation and competition on total nonstructural carbohydrates of spotted knapweed. J. Range Manage. 47:481-484.

Lacey, C.A., J.R. Lacey, P.K. Fay, J.M. Story, and D.L. Zamora. 1995. Controlling knapweed on Montana rangeland. Mont. State Univ. Ext. Ser. Circ. 311, Bozeman, Mont.

Locken, L.J. and R.G. Kelsey. 1989. Cnicin concentrations in Centaurea maculosa, spotted knapweed. Biochem. Syst. Ecol. 15:313-320.

Olson, B.E. 1999. Grazing and weeds. p. 85-96. In: R.L. Sheley and J.K. Petroff (eds.), Biology and management of noxious rangeland weeds. Oregon State University Press, Corvallis, Ore.

Olson, B.E. and R.G. Kelsey. 1997. Effect of Centaurea maculosa on sheep rumen microbial activity and mass in vitro. J. Chem. Ecol. 23:1131-1144.

Olson, B.E. and R.T. Wallander. 1997. Biomass and carbohydrate status of spotted knapweed and Idaho fescue after repeated grazing. J. Range Manage. 50:409-412.

Olson, B.E., R.T. Wallander, and J.R. Lacey. 1997. Effects of sheep grazing on a spotted knapweed-infested Idaho fescue community. J. Range Manage. 50:386-390.

Pfister, J.A., F.D. Provenza, G.D. Manners, D.R. Gardner, and M.H. Ralphs. 1997. Tall larkspur ingestion: can cattle regulate intake below toxic levels? J. Chem. Ecol. 23:759-777.

Provenza, F.D. 1996. Acquired aversions as the basis for varied diets of ruminants foraging on rangelands. J. Anim. Sci. 74:2010-2020.

Provenza, F.D., C.B. Scott, T.S. Phy, and J.J. Lynch. 1996. Preference of sheep for foods varying in flavors and nutrients. J. Anim. Sci. 74:2355-2361.

SAS. 1988. Statistical analysis system. SAS Institute Inc. Raleigh, N.C.

Shipley, L.A. 1999. Grazers and browsers: how digestive morphology affects diet selection. pp. 20-27. In: K.L. Launchbaugh, J.C. Mosley and K.D. Sanders (eds.), Grazing behavior of livestock and wildlife. Idaho Forest, Wildlife and Range Exp. Stat. Bull. \#70, Univ. Idaho, Moscow, Ida.

Tilley, J.M.A. and R.A. Terry. 1963. A twostage technique for the in vitro digestion of forage crops. J. Brit. Grassl. Soc. 18:104-111.
Tyser, R.W. and C.H. Key. 1988. Spotted knapweed in natural area fescue grasslands: An ecological assessment. Northwest Sci. 62:981-987.

U.S.D.A. 1983. Soil Conservation Service. Technical Guide. Bozeman, Mont.

U.S.D.A. 1995. Natural Resources Conservation Service. Gallatin County Soil Survey. Bozeman, Mont.

Watson, A.K. and A.J. Renny. 1974. The biology of Canadian weeds. Centaurea diffusa and C. maculosa. Can. J. Plant Sci. $54: 687-701$. 